\title{
Comparative performance of modified full-length and truncated Bacillus thuringiensis-cry $1 A c$ genes in transgenic tomato
}

\author{
Bhupendra Koul ${ }^{* *}$, Reena Yadav², Indraneel Sanyal ${ }^{2}$ and Devindra Vijay Amla²
}

\begin{abstract}
Background: Bt-cry 1 Ac gene has been reputedly effective against Helicoverpa armigera a notorious lepidopteran pest. Reports on the expression of full-length and truncated crylAc genes in plants for effective resistance against Helicoverpa sp. have been documented however, their performance is still ambiguous. Moreover, the question remains to be addressed that truncation of $3^{\prime}$ end of the native gene was documented and suggested for active insecticidal toxin production while the most successful transgenic event(s) of commercialized-cotton are based on full-length of the cry gene. Therefore, we performed a comparative study on the efficacy of the two versions of cry $1 A c$ genes (full-length: 3,510 bp and truncated: 1,845 bp) in $T_{0}$ and $T_{1}$ transgenic tomato plants and analyzed the extent of protection against $H$. armigera and also compared the results with our previous findings related to a successful transgenic tomato line Ab25E, expressing $c r y 1 A b$ gene. The integration of $c r y\rceil A c$ gene(s) in $T_{0}$ transgenic plants and its inheritance in $T_{1}$ progeny was observed by PCR, RT-PCR and Southern blot hybridization analysis while, the toxin integrity, expression and toxicity was monitored by Western immunoassay, DAS-ELISA and insect bioassay respectively.

Results: An average transformation frequency and Bt-Cry protein content of $16.93 \pm 2.10$ and $0.0020-0.0128 \%$ of total soluble protein (TSP) was obtained with pRD400 vector (Trcry TAc) while, a much lower value of $9.30 \pm 2.041$ and $0.0001-0.0026 \%$ of TSP was observed with pNBRI-1 vector (FIcry $1 A c)$, respectively. The promising Trcry $1 A c T_{0}$ transgenic plants and their $T_{1}$ progeny gave full protection from $\mathrm{H}$. armigera. Although Flcry1 Ac gene showed lower transformation frequency and lower expression, it showed higher toxicity to H. armigera when compared with truncated Trcry 1 Ac gene.

Conclusions: The full-length cry $1 A c$ gene can be redesigned for higher expression and performance in dicots or a hybrid gene could be designed having a blend of strong receptor binding and stable expression characteristics for enhanced efficacy and toxicity to the susceptible insects.
\end{abstract}

Keywords: Agrobacterium tumefaciens; Cry1Ac toxin; Tomato transformation; Leaf-disc; Helicoverpa armigera; Insect mortality

\section{Background}

By the year 2050, the global population is expected to rise above nine billion. While, at the same time it is sure that the existing arable land is expected to decrease significantly due to anthropogenic activities related to urbanization and neglecting agricultural crop losses due to insect pests. The worldwide pre-harvest crop losses have been estimated to be $13.8 \%$ from insects and other

\footnotetext{
* Correspondence: bhupendra.18673@lpu.co.in

'Department of Biotechnology and Biosciences, Lovely Professional University (LPU), Jalandhar-Delhi G.T. Road (NH-1), Phagwara 144411, Punjab, India

Full list of author information is available at the end of the article
}

arthropods, $11.6 \%$ from disease and $9.5 \%$ from weeds (Chrispeels and Sadava 1994). The conventional methods of crop protection rely mainly on the use of synthetic agrochemicals but, they have a significant drawback of environmental contamination and toxicity to non-target organisms, including humans themselves. It is the moral duty of environmentalists and molecular biologists to judiciously introduce healthier strategies to cope with the problem of insect pests and resistance management, for sustainable agricultural productivity.

The most widely used and well documented approach in this context is the insecticidal crystal protein (cry) genes of Bacillus thuringiensis (Bt) coding different 
insecticidal $\delta$-endotoxins specific to different group of insects (Schnepf et al. 1998). These toxins are highly specific to the target insects, non-toxic to animals and human beings, non-hazardous and eco-friendly (Schnepf et al. 1998; Gatehouse 2008). Therefore, these are potent "biopesticides" (Sharma 2010; James 2012). The Cry1A group of toxin(s) are effective against lepidopteran insects which are the major group infecting several agricultural crop plants in field. The mode of action of Cry1Ac toxin can be best explained by the 'Jurat-Fuentes model' which suggests that cytotoxicity is due to the synergistic effect of osmotic lysis and cell signaling process, and involves the features of both the 'Bravo model' and the 'Zhang model' of toxin mode of action (Jurat-Fuentes and Adang 2006; Pardo Lopez et al. 2013).

Cotton transgenics developed by the transfer of modified Bt-cry1Ac and Bt-cry1Ac + $2 A b$ genes and commercialized as Bollgard I and II respectively, are the great success stories in agricultural biotechnology, for providing protection against lepidopteran insects, thereby increasing the crop yield (Perlak et al. 2001; Purcell et al. 2004; Sanahuja et al. 2011). The major limitation in the development of transgenic plants with Bt-cry $1 A$ genes is the low expression of native gene in plants, which has been attributed to instability of transcript, poor stability of the toxin protein in plant environment and altered codon usage in plants (Murray et al. 1989). However, it is not possible to use the complete toxin encoding genes in plants because protoxins are not sufficiently soluble in plant cells due to low $\mathrm{pH}$ of 7.6 , since higher $\mathrm{pH}$ above 9.5 is required for solubility of the protoxins (Peferoen 1997; Shrivastava 2012). This problem is circumvented by using cry genes with 3' truncation which produce fully activated toxin molecules and remain in solubilized form in plant cell. Two approaches have been tried to increase the expression of Cry1A toxins in genetically modified plants, (1) selective removal of deleterious DNA sequences by site-directed mutagenesis and (2) completely modified sequences of cry genes with plant-optimized codon usage for enhanced expression in plants. The later approach has led to 100 fold increase in the expression levels of $c r y 1 A b$ and $c r y 1 A c$ genes in tobacco, tomato and other crop plants (Perlak et al. 1991; Koziel et al. 1993). The modified cry gene had about $65 \%$ nucleotide homology with the native gene while $\mathrm{G}+\mathrm{C}$ content was increased from $38 \%$ to $65 \%$ along with codon optimization for over expression in higher plants. Perlak et al. (1990) had reported that the truncated cry gene of B. thuringiensis var. kurstaki HD-73 strain showed detectable expression compared to fulllength cry gene in transgenic cotton (Perlak et al. 1990). The transgenic cotton plants harbouring truncated $B$. thuringiensis cry $1 A c$ gene showed high level of activity against Manduca sexta resulting in 100\% mortality. The laboratory trials were further confirmed and demonstrated with field trials. However, the same group reported that full-length gene rather than a truncated gene provides reasonable protection from Heliothis virescens (tobacco budworm) (Perlak et al. 2001; Rawat et al. 2011). They came up with an event that was used to develop Bt-transgenics resistant to damage by Helicoverpa armigera, the major target pest in India, China and Australia.

Reports on the expression of both the full-length and truncated $c r y 1 A c$ genes for effective resistance against insects have been documented but, unfortunately the performance of Cry1Ac toxin encoded by full-length and truncated $c r y 1 A c$ gene in plants is still not clear (Kranthi et al. 2005; Rawat et al. 2011). The routine recovery of transgenic events expressing high-level of Cry1Ac toxin is a rare, random and vexatious issue (Rawat et al. 2011). Also, the question remains to be addressed that truncation of 3 ' end of gene was documented and suggested for active insecticidal toxin production while the most successful transgenic event(s) of cotton for field performance and commercialization are based on full-length of the cry gene. Therefore, we performed a comparative study on toxicity and performance of two versions of $c r y 1 A c$ gene using tomato as a model system, for development of $H$. armigera resistant, stable transgenic plants.

\section{Results}

\section{Development of transgenic tomato plants}

Agrobacterium-mediated tomato transformation was performed with vector constructs (Figure $1 \mathrm{~A}$ and $\mathrm{B}$ ) pRD400 harbouring truncated $c r y 1 A c$ gene $(\operatorname{Tr} c r y 1 A c)$ and pNBRI-1 harbouring full-length $c r y 1 A c$ gene (Flcry1Ac) using the modified procedure. The explants which regenerated during kanamycin selection cycle (responding explants) were putative transformants. The percentage transformation frequency was determined as independent transgenic events received after the second selection divided by total number of explants, multiplied by 100. An average transformation frequency of $16.93 \pm 2.10$ and $9.30 \pm 2.04$ was observed with pRD400 and pNBRI-1 respectively, as shown in Additional file 1: Table S1. The results of molecular characterization of $T_{0}$ and $T_{1}$ transgenic tomato plants of the respective constructs have been discussed consecutively under respective heading: [A] Truncated cry1Ac gene (vector pRD400) and [B] Fulllength $c r y 1 A c$ gene (vector pNBRI-1). To avoid confusion, the transgenic events obtained with Trcry1Ac were designated as Ac 1-Ac 30 and that with Flcry1Ac as FlAc 1-FlAc 30.

The $\mathrm{T}_{0}$ transgenic plants developed with pRD400 vector harbouring $\operatorname{Tr} c r y 1 A c$ gene showed normal growth and flowering ( $43 \pm 1.83$ days), except the fruit size. The size of fruits was reduced compared to the control and the average weight of the fruits per plant was calculated 


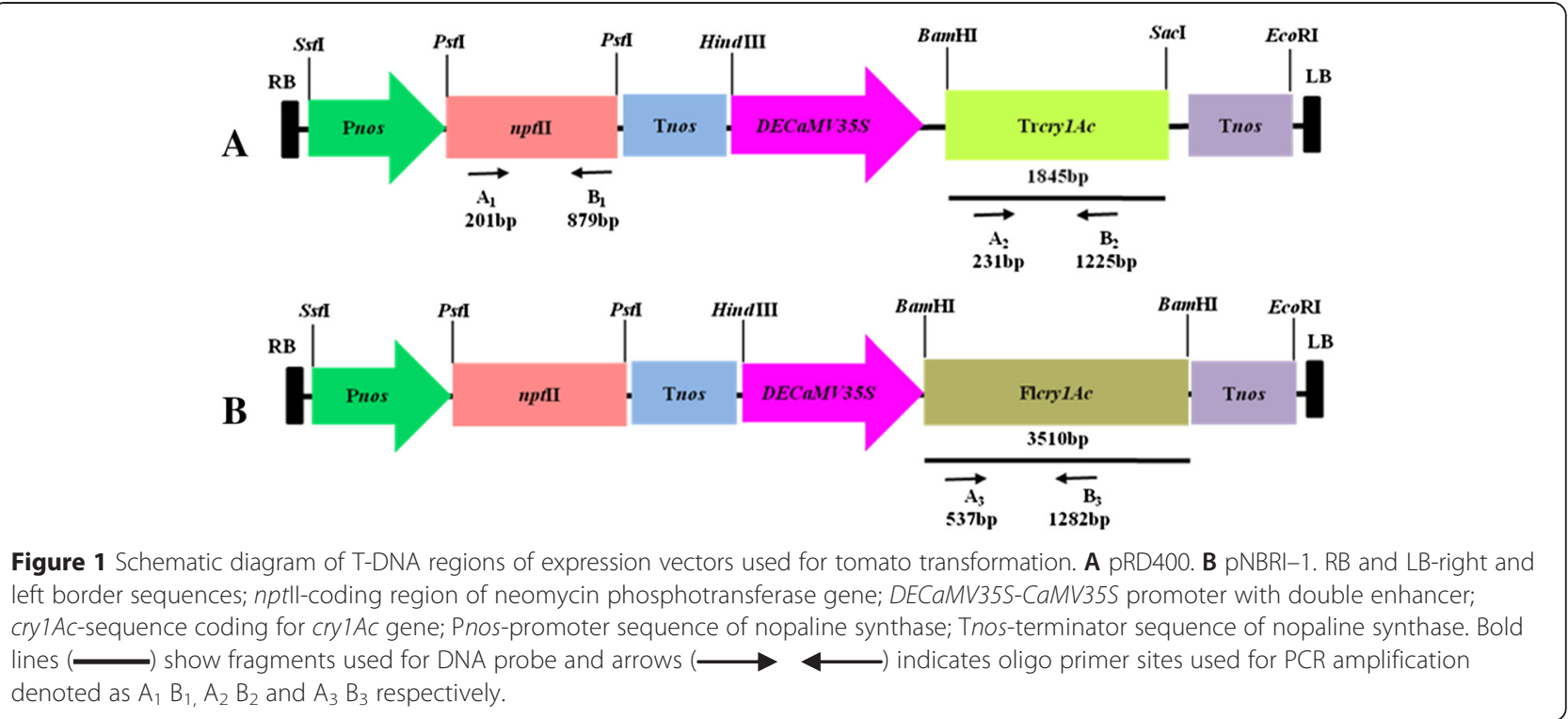

to be $18.64 \pm 0.98 \mathrm{gm}$. It was interesting to note that although the seed count was reduced with $35.4 \pm 7.5$ seeds (1.9 seeds per gram of tomato pulp) compared to the control tomato bearing $62.6 \pm 12.60$ seeds per tomato (2.57 seeds per gram of tomato pulp), but the shape and size of the seeds were normal as the control. Seed germination was not affected by the cry $1 A c$ gene and the $T_{1}$ plants attained an average height of $109.54 \pm 20.80 \mathrm{~cm}$ with $43.20 \pm 4.08$ average number of leaves and 5.0 \pm 2.10 average number of fruits per plant (Table 1 ). The $\mathrm{T}_{0}$ plants developed with vector pNBRI-1 harbouring Flcry1Ac gene did not show any abnormality in their growth, and flowering. These transgenic plants attained an average height of $116.4 \pm 6.10 \mathrm{~cm}$ with $56.31 \pm 11.52$ average number of leaves (Table 1 ). The size of the fruits was markedly reduced compared to the control untransformed tomato plants while the fruit number was found to be similar to that of control. The average number of fruits per plant was observed to be $16 \pm 7.5$ and the average weight of tomatoes was found to be $18.5 \pm 1.34$ gm with $29 \pm 2.82$ average numbers of seeds per tomato (1.56 seeds per gram of tomato pulp).

\section{[A] Truncated cry1Ac gene (vector pRD400)}

\section{Molecular characterization of transformants}

A total of thirty independently selected $\mathrm{T}_{0}$ transgenic tomato plants were screened for the presence of cry $1 \mathrm{Ac}$ and nptII gene by PCR amplification using the specific set of primers. These plants showed expected amplicon of 995 and 678 bp for cry1Ac and nptII genes respectively (Figure $2 \mathrm{~A}-\mathrm{C}, \mathrm{E}-\mathrm{G}$ ). The presence of both the genes (cry1Ac and nptII) indicated intact integration of the transgene and the selection marker. Out of thirty $\mathrm{T}_{0}$ transformants RT-PCR analysis of ten randomly selected plants was performed to confirm the formation of cry $1 A c$ and $n p t I I$ gene transcript. The first strand cDNA was amplified using specific set of primers which showed expected amplicons of 995 and 678 bp for cry $1 A c$ and $n p t I I$ genes respectively (Figure $2 \mathrm{D}, \mathrm{H}$ ).

\section{Determination of transcript level by real-time PCR}

The transcript level was analyzed by real time PCR in seven randomly selected $\mathrm{T}_{0}$ transgenic tomato plants expressing $c r y 1 A c$ gene. The expression level of plant ID Ac1 was very low and was therefore taken as a reference which was denoted as TC (transformed control). The comparative transcript level ranged from 2.18 (Ac 9), 0.61 (Ac 11), 3.2 (Ac 16), 2.4 (Ac 21), 3.7 (Ac 25) and 5.1 (Ac 26) folds higher to Ac 1 respectively (Figure 2I). No amplification was observed in non-transformed control plant and on an average the transgenic lines showed 2.9 folds enhanced expression over the reference (Ac 1).

\section{Southern blot hybridization analysis and Western immunoassay}

The transformants confirmed by PCR and RT-PCR were further analyzed by Southern blot hybridization. The genomic DNA from transformed and untransformed plants was digested with EcoRI as there is a unique site for this restriction enzyme in the T-DNA region of the binary vector pRD400. Southern blot hybridization of eight $\mathrm{T}_{0}$ plants with $1,845 \mathrm{bp} B a m \mathrm{HI}$ and EcoRI fragment of $\operatorname{cry} 1 A c$ gene probe revealed that they were independent transgenic events. Most of the promising $\mathrm{T}_{0}$ transgenic plants showed single and double copy insertion while only one plant (Ac 26) showed triple copy insertion of the transgene and the hybridizing fragments ranged from 4.5-15.5 kb (Figure 3A). Whereas, genomic 
Table 1 Comparative assessment of growth parameters of $\mathrm{T}_{0}$ plants developed with vectors pRD400 and pNBRI-1

\begin{tabular}{|c|c|c|c|c|c|c|c|c|c|}
\hline $\begin{array}{l}\text { Vector } \\
\text { construct }\end{array}$ & $\begin{array}{l}\text { Cry toxin } \\
\text { (\% of tsp) }\end{array}$ & $\begin{array}{l}\text { Average plant } \\
\text { height }\end{array}$ & $\begin{array}{l}\text { Average number } \\
\text { of leaves }\end{array}$ & $\begin{array}{l}\text { aOnset of flowering } \\
\text { (days after hardening) }\end{array}$ & $\begin{array}{l}{ }^{b} \text { Average number } \\
\text { of fruits/plant }\end{array}$ & $\begin{array}{l}\text { Number of } \\
\text { seeds/fruit }\end{array}$ & $\begin{array}{l}\text { CDry weight } \\
\text { yield (gm) }\end{array}$ & $\begin{array}{l}{ }^{\mathrm{d}} \text { Number of } \\
\text { seeds/gm of fruit }\end{array}$ & $\begin{array}{l}\% \text { germination } \\
\text { of } \mathrm{T}_{1} \text { seeds }\end{array}$ \\
\hline Control & - & $106.4 \pm 6.87$ & $42.00 \pm 7.21$ & $30 \pm 1$ & $14.0 \pm 1.93$ & $62.6 \pm 12.60$ & $520 \pm 8.832$ & 2.57 & $75 \pm 2.95$ \\
\hline pRD400 & $0.0020-0.013$ & $109.54 \pm 20.8(0.373)$ & $43.20 \pm 4.08(0.3767)$ & $43 \pm 1.83(0.000054)$ & $\begin{array}{l}5.0 \pm 2.10 \\
(0.000014)\end{array}$ & $35.4 \pm 7.5(0.00257)$ & $470 \pm 5.47(0.00204)$ & 1.9 & $49 \pm 2.58$ \\
\hline pNBRI-1 & $0.0001-0.003$ & $116.40 \pm 6.10(0.0205)$ & $56.31 \pm 11.52(0.010)$ & $36 \pm 1.41(0.0079)$ & $16.0 \pm 7.5(0.2256)$ & $29.0 \pm 2.32(0.000006)$ & $496 \pm 10.95(0.0047)$ & 1.57 & $32 \pm 3.00$ \\
\hline
\end{tabular}

averall average of the days of onset of flowering, in 30 transgenic tomato plants of each group.

${ }^{\mathrm{b}}$ Average number of fruits per plant in 30 transgenic tomato plants of each group.

A Average dry weight of 30 transgenic tomato plants of each group of plants.

A Average dry weight of 30 transgenic tomato plants of each group of plants.

Vaverase number of seeds (per gram of 30 plants of each group. was significant. 


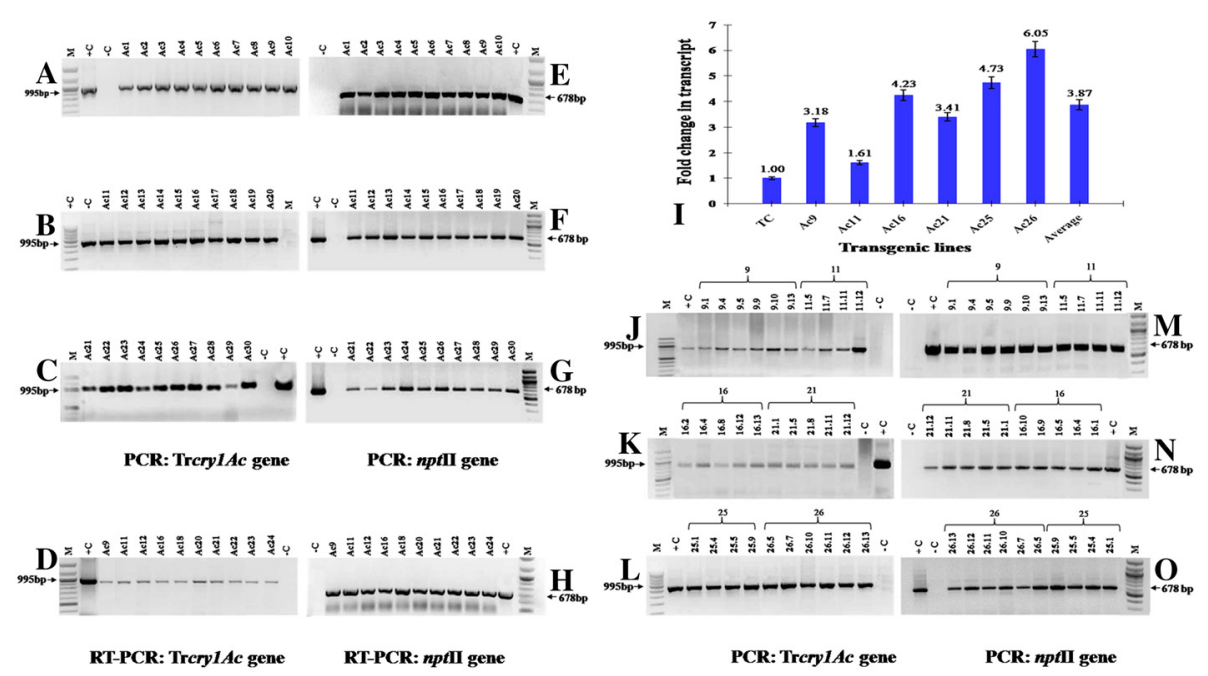

Figure 2 Screening of $T_{0}$ and $T_{1}$ Trcry 7 Ac transgenic tomato plants. A-C PCR amplification of 995 bp of cry $1 A c$ gene. D-F 678 bp of nptll gene using gene specific primers in thirty $T_{0}$ transgenics. G, H RT-PCR analysis of ten randomly selected To transgenic tomato plants of cry 7 Ac showing 995 bp cry $7 A c$ gene and 678 bp nptll gene transcripts. M - 100 bp DNA ladder (NEB, USA). -C - non-transgenic control plant, +C - plasmid DNA positive control. I Realtime analysis for Bt-cry 7 Ac transcript levels in six $\mathrm{T}_{0}$ transgenic tomato plants. TC - Transgenic plant with low expression of Bt-toxin used as control. J-O PCR amplification of 995 bp of cry 7 Ac gene and 678 bp of nptll gene using gene specific primers inT $T_{1}$ progeny of promising $T_{0}$ parents. $M-100$ bp DNA ladder (NEB, USA). -C : non-transgenic control plant, +C : plasmid DNA positive control.

DNA from untransformed control tomato plants did not show any hybridization signal with crylAc gene probe. Western immunoassay of ten transgenic plants including those 8 plants which passed the Southern blot hybridization analysis was performed using the cell-free extract of leaf tissues. The protein blots showed a light band of approximately $65 \mathrm{kDa}$ which was similar to the positive control (Figure 3B).

\section{Protein expression and corresponding insect mortality}

The expression level of $c r y 1 A c$ gene in $\mathrm{T}_{0}$ and $\mathrm{T}_{1}$ transgenic tomato plants was analyzed through DAS-ELISA and calculated as percentage of Bt-protein of total soluble protein (TSP). Cry1Ac toxin content in thirty independent $\mathrm{T}_{0}$ plants ranged between $0.0020-0.0128 \%$ of TSP. The resistance bestowed against fruit worm $H$. armigera corresponding to the Cry1Ac toxin is shown in Additional file 2: Table $\mathrm{S} 2$ and Figure 4A.

Few $\mathrm{T}_{0}$ plants expressing Cry $1 \mathrm{Ac}$ toxin above $0.02 \%$ of total soluble protein (TSP) with plant ID Ac $9(0.0240 \%)$, Ac $16(0.0380 \%)$, Ac 21 (0.0255\%), Ac $25(0.0386 \%)$ and Ac 26 (0.1259\%), were selected for further analysis of their $\mathrm{T}_{1}$ progeny. The $\mathrm{T}_{1}$ seeds of these transgenics plants (plant ID Ac 9, Ac 11, Ac 16, Ac 21, Ac 25 and Ac 26) were grown on kanamycin selection media to study the segregation pattern and further molecular characterization

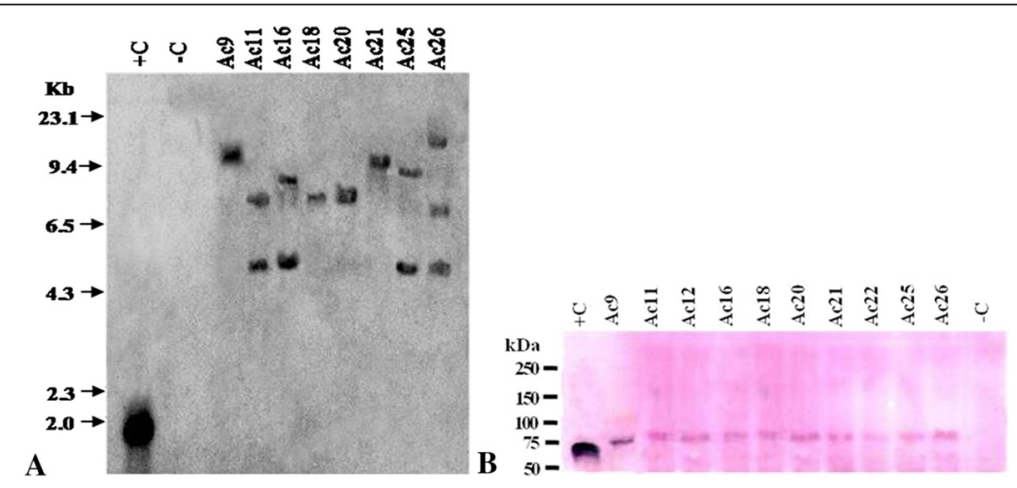

Figure 3 Southern blot hybridisation and Western immunoblot analysis of $T_{0}$ Trcry 7 Ac transgenics. A Southern blot hybridisation analysis of eight $\mathrm{T}_{0}$ transgenic tomato plants of cry $7 \mathrm{Ac}$ probed with 1,845 bp radiolabelled BamHI-EcoRl fragment of cry $7 \mathrm{Ac}$ gene. $+\mathrm{C} 1,845$ bp cry $1 \mathrm{Ac}$ gene fragment; $-\mathrm{C}$ Untransformed control plant. B Western immunoblot analysis of ten $T_{0}$ transgenic plants, with crude protein extract; lane 1: purified Cry1Ac protein; lane 12 : untransformed control plant protein; lane 2-11: protein samples of ten transgenic plants. The transgenic samples gave a band of $\sim 65 \mathrm{kDa}$, similar to the positive control. $-\mathrm{C}$ : Untransformed control plant. 

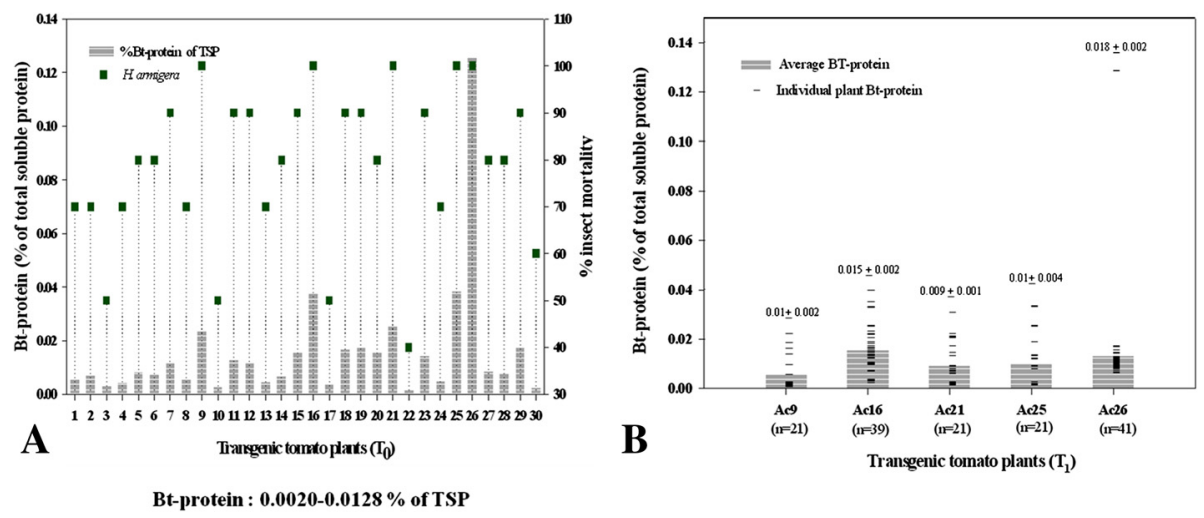

Figure 4 Expression of Trcry $7 A c$ gene in transgenic plants. A Thirty $T_{0}$. B Selected $T_{1}$ transgenics. The gray shaded vertical bar represents the average content of Bt-Cry1Ac protein. The squares (green square) represent the average of the $\%$ mortality status of $\mathrm{H}$. armigera, when subjected to the leaves of $T_{0}$ and respective $T_{1}$ transgenic tomato plants. ' $n$ ' is the number of $T_{1}$ transgenic population from each parent.

of the segregated kanamycin resistant population. These highly expressing $\mathrm{T}_{1}$ progeny of respective $\mathrm{T}_{0}$ parents gave PCR amplification of the expected amplicon of 995 and $678 \mathrm{bp}$ for $c r y 1 A c$ and $n p t \mathrm{II}$ genes, respectively (Figure 2J$\mathrm{L}, \mathrm{M}-\mathrm{O})$. The average Cry1Ac toxin content of the progeny of Ac 9, Ac 16, Ac 21, Ac 25 and Ac 26 parents showed $0.01 \pm 0.002,0.015 \pm 0.002,0.009 \pm 0.001,0.01 \pm 0.004$ and $0.018 \pm 0.002 \%$ of TSP respectively (Figure 4B) causing $100 \%$ mortality of $\mathrm{H}$. armigera after $72 \mathrm{~h}$ of feeding on detached vegetative leaves. The control non-transgenic leaves suffered heavy damage due to voracious feeding by the insect. (Figure $4 \mathrm{~A}, \mathrm{~B})$.

Segregation of $n p t \mathrm{II}$ gene in $\mathrm{T}_{1}$ progeny was studied in these five highly expressing ELISA positive, independent transformants as shown in Additional file 3: Table S3. It was observed that the segregation ratio was Mendelian in nature with a minimum Chi-square value of 0.19 for Ac 25 and maximum value of 3.34 for Ac 16 .

\section{[B] Full-length cry1Ac gene (vector pNBRI-1)} Molecular characterization of the $T_{o}$ transgenic plants

A total of thirty $T_{0}$ transgenic plants were taken for the population study and were screened for the presence of cry $1 A c$ gene through PCR. All the plants were PCR positive and showed an expected amplicon of $768 \mathrm{bp}$ gene specific primers (Figure 5A-C). RT-PCR analysis of these plants was performed and the cDNA was amplified using gene specific primers, showing an expected amplicon of $768 \mathrm{bp}$ (Figure 5D-F). These $\mathrm{T}_{0}$ plants were also screened for the presence of $n p t I I$ gene and PCR amplification gave an expected amplicon of 678 bp (Figure 5G-I). Similarly, RT-PCR analysis for the $n p t I$ gene transcript also showed 678 bp amplicon of $n p t I I$ gene (Figure 5J-L).

\section{Protein expression and corresponding insect mortality} Bt-ELISA of all the PCR and RT-PCR positive thirty $\mathrm{T}_{0}$ transgenics was performed using pathoscreen cry1 Ab/AC
ELISA kit (Agdia, USA). Interestingly, only two plants, FLAc 7 and FLAc 11 showed detectable expression of Bt-protein content which was estimated to be 0.0015 and $0.0026 \%$ of total soluble protein (TSP), respectively (Figure 6A). Detached leaf bioassay of FLAc 7 and FLAc 11 was performed with second instar larvae of Helicoverpa armigera. Both these plants gave $100 \%$ mortality to the larvae in repeated bioassays (Additional file 2: Table S2 and Figure 6A). The leaves of FLAc 7 and FLAc 11 were also subjected to second instar larvae of Spodoptera litura and caused $20 \%$ and $30 \%$ insect mortality to the larvae, respectively (data not shown). This result indicates the specificity of cry $1 A c$ gene for $H$. armigera midgut receptors. These two plants FLAc 7 and 11 were selected for further analysis and segregation pattern of the kanamycin selection marker. Segregation of $n p t I I$ gene in $\mathrm{T}_{1}$ seeds of the two ELISA positive independent transformants FLAc 7 and FLAc 11, was analysed, as shown in Additional file 3: Table S3. The segregation ratio was Mendelian in nature with a minimum Chi-square value of 0.82 for FLAc 11 and maximum value of 1.25 for FLAc 7 .

Fiftyfive $T_{1}$ plants of FLAc 7 and fifteen plants of FLAc 11 were screened through DAS-ELISA. As expected, all the $\mathrm{T}_{1}$ transgenic tomato plants were found to be ELISA positive. The Bt-protein content of few highly expressing plants FLAc 7.2, 7.4, 7.19, 7.34, 7.37, 7.48, 11.8 , 11.9, 11.11 and 11.14 was $0.003 \%, 0.0055 \%, 0.0026 \%, 0.0021 \%$, $0.0025 \%, 0.0062 \%, 0.0178 \%, 0.0015 \%, 0.001$ and $0.0015 \%$ of TSP, respectively (Figure 6B,C). These plants were also subjected to insect bioassay with $H$. armigera and varying degrees of protection corresponding to the expression level of Bt-protein was observed. Only FLAc 7.48 and FLAc 11.8 gave $100 \%$ mortality to second instar larvae of H. armigera while FLAc 7.2, FLAc 7.4, FLAc 7.19, FLAc 7.34, FLAc 7.37 and FLAc 11.4 bestowed 80\%, 90\%, 80\%, $60 \%, 70 \%$ and $50 \%$ protection respectively, against the insect (Figure 6B,C). 

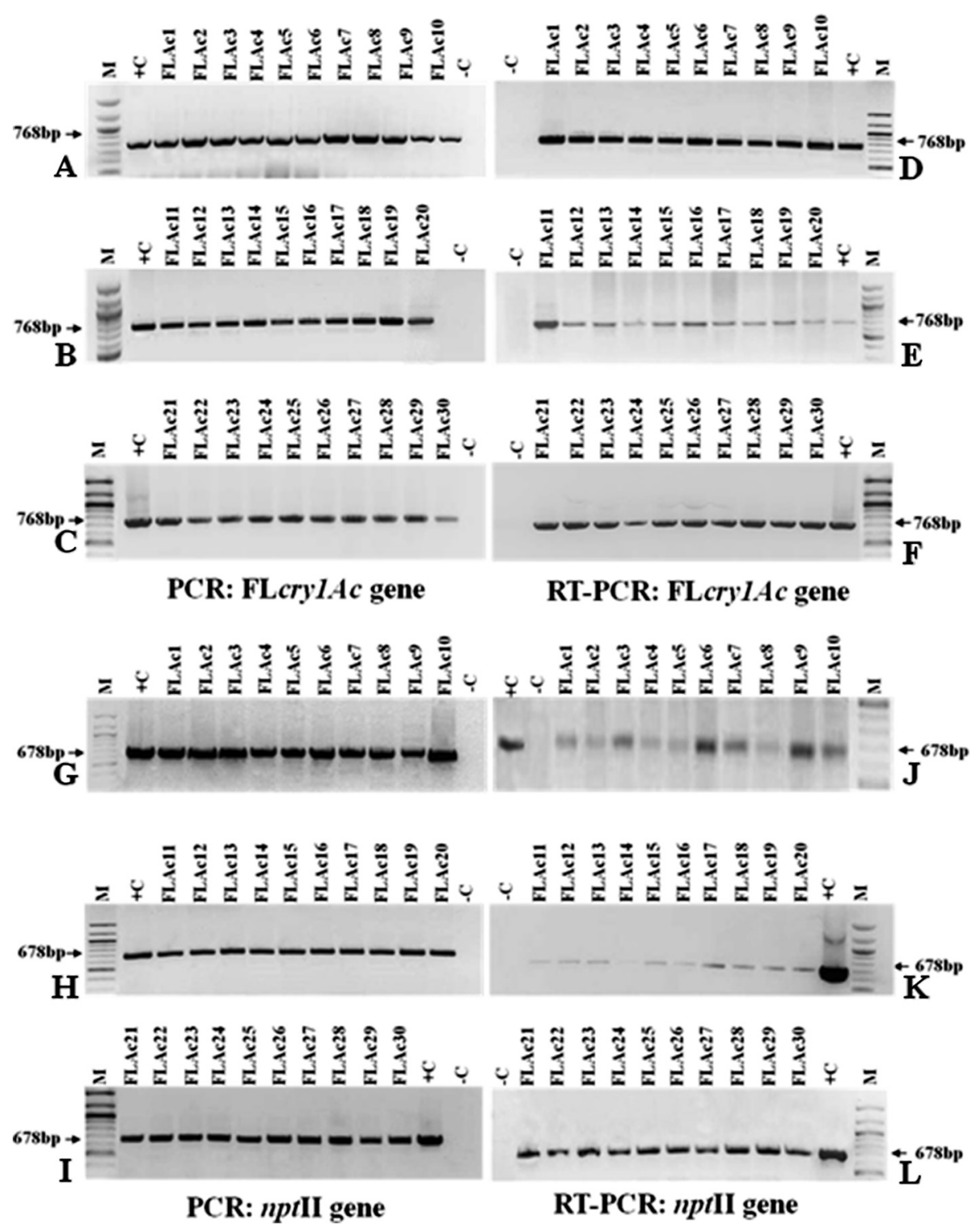

Figure 5 Molecular characterizations of T FlcrylAc transgenic tomato plants. Upper Panel A-C PCR amplification of 768 bp of Flcry 1 Ac gene using specific primers in thirty $T_{0}$ transgenics. D-F RT-PCR analysis of $T_{0}$ transgenic tomato plants showing 768 bp amplicon of cry 1 Ac gene. M : 100 bp DNA ladder (NEB, USA). -C : non-transgenic control plant, $+C$ : plasmid DNA positive control. Lower Panel G-I PCR amplification of 678 bp nptll gene using specific primers in $T_{0}$ transgenics. J-L RT-PCR analysis of $T_{0}$ transgenic tomato plants of showing $678 \mathrm{bp}$ amplicon of nptll gene. M : $100 \mathrm{bp}$ DNA ladder (NEB, USA). - C : non-transgenic control plant, $+C$ : plasmid DNA positive control.

Determination of transcript level by real-time PCR

The two $\mathrm{T}_{0}$ transgenic tomato plants, FLAc 7 and FLAc 11 were also subjected to quantitative real-time PCR. The expression level of $\mathrm{T}_{0}$ transgenic tomato plant ID FLAc 9 was very low and was therefore taken as a reference which was denoted as TC (transformed control). The comparative transcript level in transgenic plants ranged from 6.7 (FLAc 7) and 9.6 (FLAc 11), folds higher to FLAc 9 respectively (Figure 7A). No amplification was observed in non-transformed control plant and on an average the transgenic lines showed 8.1 folds enhanced expression over the reference (FLAc 9).

Molecular characterization of the $T_{1}$ progeny of promising $\mathrm{T}_{0}$ transgenic plants

All the ELISA positive $\mathrm{T}_{1}$ plants FLAc 7.2, FLAc 7.4, FLAc 7.19, FLAc 7.34, FLAc 7.37, FLAc 7.48, FLAc 11.8 and FLAc 11.14, expressing Bt-Cry1Ac toxin above $0.003 \%$, were subjected to RT-PCR analysis using gene specific primers. All the plants showed expected amplicon 


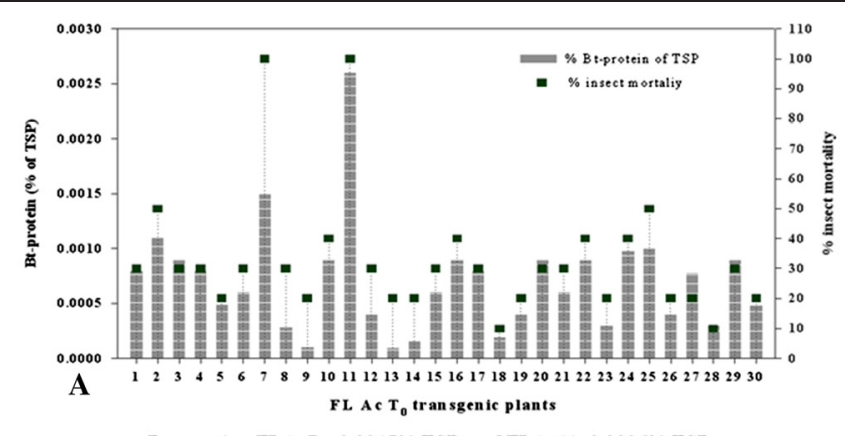

Bt-protein : FLAc7 : $0.0015 \%$ TSP and FLAc11: 0.0026\% TSP

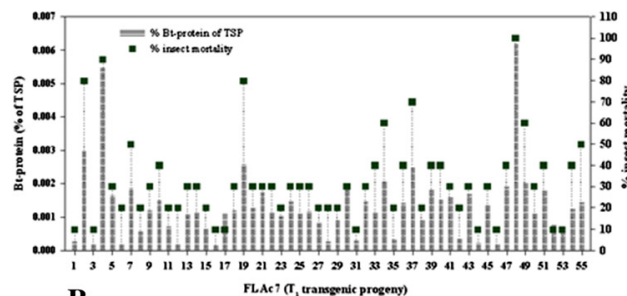

B

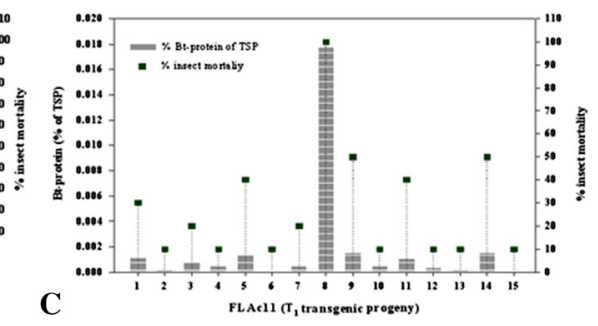

Figure $\mathbf{6}$ Expression of Flcry 1 Ac gene in transgenic plants. A Thirty $T_{0}$ transgenics. B, C $T_{1}$ progeny of FLAc 7 and 11 . The gray shaded vertical bars represents the average content of Bt-Cry1Ac protein and squares (green square) represent the average of the \% mortality status of $H$. armigera, when subjected to the leaves of $\mathrm{T}_{0}$ transgenic plants.

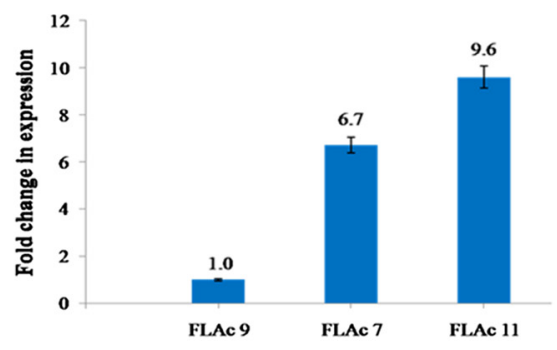

$\mathbf{A}$

To transgenic plants
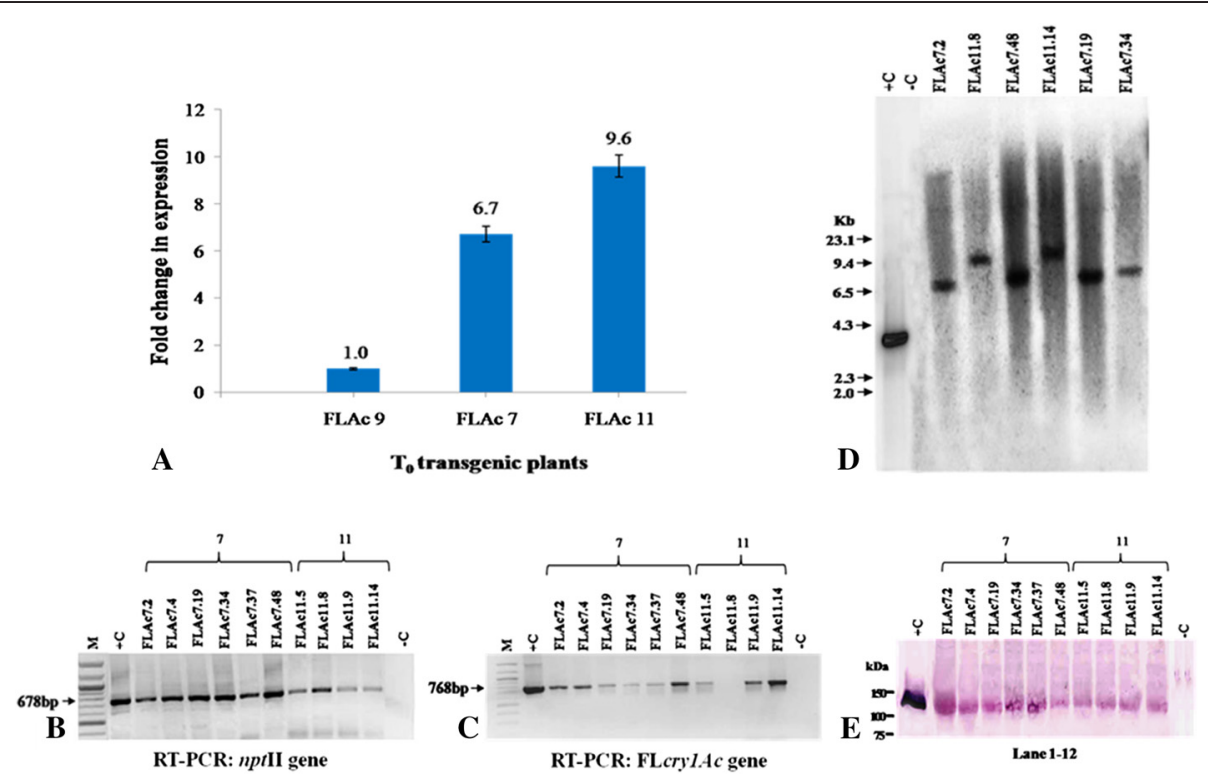

Figure 7 Molecular characterizations of $\mathrm{T}_{0}$ and $\mathrm{T}_{1}$ progeny of FIAC7 and FIAC11 transgenic tomato plants. A Comparative real-time PCR analysis of transcript in $\mathrm{T}_{0}$ Flcry 7 Ac transgenic plants showing fold change in expression with respect to FIAc 9 (low expressing transgenic plant taken as reference). Control : non-transgenic control. B, C RT-PCR and CDNA amplification of 678 bp nptll gene and 768 bp Flcry 7 Ac gene of $\mathrm{T}_{1}$ progeny using specific primers. M : 100 bp DNA ladder (NEB, USA). $-C$ : non-transgenic control plant, $+C$ : Flcry IAc gene plasmid DNA as positive control. D Southern blot probed with 3,510 bp BamHI radiolabelled frament of FlCry1Ac gene. E Western immunoblot assay performed with crude leaf protein extract, lane1 purified Cry1AC toxin protein, lane 12 : untransformed control, lane 2-11: leaf protein extracts from progeny of $\mathrm{T}_{0}$ FIAC7 and FIAc11. A protein band of $\sim 130 \mathrm{kDa}$ in transgenic plants showed hybridization with Cry1 Ac antibodies, similar to positive control. 
of 678 bp for $n p t \mathrm{II}$ gene and 768 bp for Flcry1Ac gene (Figure 7B,C). Southern blot hybridization was performed with six $\mathrm{T}_{1}$ plants (FLAC 7.2, FLAc 11.8, FLAc 7.48, FLAc 11.14, FLAc 7.19 and FLAc 7.37) using 3,510 bp Flcry1Ac gene fragment as probe. The genomic DNA from transformed and untransformed plants was digested with Sal I as there is a unique site for this enzyme in the T-DNA regions of the binary vector pNBRI-1. The hybridizing fragments ranged between $6.5-10.0 \mathrm{~kb}$ and showed single copy integration of the transgene (Figure 7D). Western immunoblot analysis of $T_{1}$ progeny of FlAc 7 and FlAc 11 revealed a specific but fuzzy band of approximately $130 \mathrm{kDa}$, in all the plant samples. The non-transgenic control lane did not show any colour signal (Figure $7 \mathrm{E}$ ). The $\mathrm{T}_{1}$ transgenic plant FLAc 11.8 showed complete protection against second instar larvae of Helicoverpa armigera and was finally selected as a promising event (Figure 6C).

\section{Discussion}

The first transgenic crop that was commercialized in the USA was Bt-cotton. It was developed to express fulllength synthetic cry1Ac-like Bt-gene sequence and its worldwide acceptance has grown exponentially since its introduction. This product has significantly reduced cotton production costs and the recurrent use of pesticides by providing a promising alternative for the control of Heliothis virescens, Helicoverpa zea, and Pectinophora gossypiella. Bt-cotton ensures considerable agronomic, economic and environmental benefits to its growers. The information on Cry-toxin receptors, the stability and efficacy of different Cry-toxins and the resistance mechanisms developed by the target pests is crucial to maintain the utility of $B t$-transgenic technology.

There are few reports available in order to prove the efficacy and the stability of native full-length $c r y 1 A c$ gene and its expression, in transgenic plants (Barton et al. 1987; Vaeck et al. 1987; Perlak et al. 1990; De Rocher et al. 1998). In most of the reports the research groups have tried to depict the performance of the $B t$-genes in $\mathrm{T}_{0}$ primary transformants or did not perform a population study in subsequent progenies to confirm the stability of cry gene expression in terms of growth characteristics and inheritance. Our results obtained from PCR, Southern blotting and RT-PCR analyses of transgenic tomato plants have confirmed the stable integration of Trcry1Ac and Flcry $1 A c$ genes in $\mathrm{T}_{0}$ plants and their respective $\mathrm{T}_{1}$ progeny. The different sizes of hybridizing genomic DNA fragments $(\sim 4.5-15.5 \mathrm{~kb})$ of transgenic tomato plants with the respective $c r y$ gene-probe indicated that they resulted from the independent stable T-DNA integration event into the plant genome. The Bt-toxin content of $\mathrm{T}_{0}$ transgenic population of tomato developed with modified Trcry1Ac and modified Flcry1Ac genes ranged between $0.0024-0.126 \%$, and $0.0001-0.0026 \%$ of TSP, respectively.
Although, all the $\mathrm{T}_{0}$ transgenics were PCR and RT-PCR positive however, a remarkable difference was observed in the number of true transgenics (transgenics with detectable expression) obtained with equal number of transformation experiments and overall transformation frequencies obtained with both vector constructs. A higher transformation frequency of $16.93 \% \pm 2.10$ was observed with vector harbouring modified TrcrylAc gene and a much lower value of $9.30 \pm 2.041$ with vector harbouring Flcry $1 A c$ gene. The level of transgene expression in plants is generally unpredictable and may vary with different vector-constructs and also independent transformants with same vectorconstruct.

The $\mathrm{T}_{1}$ seeds of $\operatorname{Tr} c r y 1 A c$ transgenic tomato were subjected to kanaycin selection. It was observed that the average Cry1Ac toxin content of the progeny of Ac 9, Ac 16, Ac 21, Ac 25 and Ac 26 were less than their respective parents. After segregation of the Bt-transgene very few candidate plants retained expression level similar to their respective parents. There are certain factors which do influence transgene expression and its stability in transgenic plants and may lead to highly variable expression within populations of plants from individual parents, developed in the same transformation experiment. The position effect being the most important factor reflects the significant role of genomic DNA adjoining the site of transgene integration (Wilson et al. 1990). Another factor is the copy number, intactness of the transgenes and their relative arrangement, which influences the probability of physical interactions, recombination within the locus and the induction of gene silencing (Hobbs et al. 1993; Heinrichs 2008). The probable cause for low expression of the Trcry1Ac- $\mathrm{T}_{1}$ population is, during segregation the transgenic locus is directed to or near a heterochromatin rich region thereby producing variants with a lower and varied Btcontent. But in case of Flcry1Ac transgenics, the gene shows single copy integration and is segregated along the gene rich euchromatin region of the chromosome.

Our results also suggest that Flcry1Ac gene is comparatively poorly expressed than Trcry1Ac, despite the optimal conditions of transformation and the overall transformation frequency was low. An interesting observation was noticed when $T_{0}$ transgenics developed with pRD400 and pNBRI-1 vector-constructs were subjected to insect bioassay with $H$. armigera. Although highly expressing transgenic plants expressing Trcry1Ac gene showed protection against $H$. armigera whereas, only two low expressing transgenic events harbouring Flcry $1 A c$ gene, (FlAc7 and FlAc11) repeatedly showed fullprotection against $H$. armigera. This observation made us to realize that although Flcry1Ac gene showed a lower transformation frequency and expression but the promising events were highly toxic to $H$. armigera. Certainly, 
there is a scope for more improvement of Flcry1Ac gene for higher expression in transgenic plants. These results can be co-related to the most successful transgenic event Monsanto 531 which was developed with full-length modified cry1Ac-like gene and commercialized as Bollgard cotton, for complete protection against bollworm complex (Perlak et al. 2001; Purcell et al. 2004).

There are not many reports concerning the development of promising transgenic plants over-expressing variants of Cry1Ac toxin (native truncated and native full-length or modified and truncated or modified full-length). It may be attributed to toxic or suppressive response of Cry1Ac toxin during early stage of plant cell development (Barton et al. 1987; De Rocher et al. 1998; Rawat et al. 2011). It was reported by Rawat et al. 2011 that high expression of $c r y 1 A c$ gene acts as a negative selection and regenerated plants cells with low expression of the gene are the ones which actually proliferate. The same group reported that certain morphological abnormalities occur in in vitro regeneration of explants after transformation with $c r y 1 A c$ gene and in the growth of the transgenic plants. Our results of transformation frequency with Flcry1Ac gene can be compared with it. In the present study, although the transformation frequency was reduced but we did not come across morphological abnormalities in the regenerating explants transformed with $c r y 1 A c$ genes. The only growth related abnormality which was observed in few $\mathrm{T}_{0}$ plants during glass house-stage was their delayed flowering and fruit setting. This problem was confirmed after observing the floral morphology of pRD400 transformants where the stigmal apparatus was longer than the filaments and projected outside the unopened flower. As tomato is strictly self pollinated crop because of cleistogamous nature of flowers, the stigma and style should reside within the unopened flower. But, to our surprise the $T_{1}$ generation did not face the same problem. In the study of Sachs et al. (1998) involving the inheritance of the $c r y 1 A c$ gene in MON249 event in cotton, it has been hypothesized that reduced fitness of some of the transgenic lines may be a result of direct insertion effects leading to the down-regulation of one or more native genes or the result of a linked somaclonal variation (Sachs et al. 1998).

It was interesting to note that apart from a low Bt-toxin protein content Flcry1Ac-transgenics gave full protection to $H$. armigera which was comparable to Trcry1Ac-transgenics expressing higher levels of Bt-toxin. In a recent study of Gomez et al. (2014) on Manduca sexta insect bioassay, they have reported that the insecticidal activity of modified Cry1Ab toxin (active toxin) was 8-fold lower than the modified Cry1Ab protoxin. Their experimental data show protoxin molecules trigger the formation of pre-pore structures and supports the pore-formation model involving sequential interaction with different midgut receptor which culminates to pore formation in the gut membrane and insecticidal activity. These findings could be related to our study and the question as to why the full-length Cry1Ac toxin at a lower concentration is effective than the truncated Cry1Ac toxin can be answered. The modified full-length Cry1Ac toxin, although at a lower expression levels, efficiently induces oligomerization, prepore formation and insecticidal activity compared to modified truncated Cry1Ac toxin at higher expression levels. These results suggest the importance of modified full-length cry $1 A c$ gene for stability and integrity of the insect-resistance trait compared to truncated version of cry $1 A b$ or $c r y 1 A c$ genes alone (Koul 2013). Thus, the functional role of protoxin segments in the pore formation is yet to be analysed.

The truncated $c r y 1 A b$ gene bears $>80 \%$ homology with truncated $c r y 1 A c$ gene. In our previous findings, we raised Bt-cry $1 \mathrm{Ab}$ transgenic tomatoes and performed similar tests. A maximum transformation frequency of $28.20 \%$ was obtained with binary vector pBIN200 harbouring the modified truncated $1,845 \mathrm{bp}$ cry $1 \mathrm{Ab}$ gene (Koul 2014b). The best transgenic line Ab25 E, expressing $0.47 \pm 0.01 \%$ Cry $1 \mathrm{Ab}$ toxin of total soluble protein (TSP) was finally selected in the $\mathrm{T}_{1}$ generation from the segregating population showing $100 \%$ mortality to the second instar larvae of $H$. armigera and S. litura and minimal damage to leaves and fruits (Additional file 4: Figure S1). The success of transgenic event Ab25E expressing modified truncated $c r y 1 A b$ may be attributed to possible incorporation of $c r y 1 A b$ transgene in euchromatin hot spot region of the genome. The position effect on transgene expression probably reflects pre-existing features of the insertion site, such as proximity to genome enhancers and degree of chromatin condensation (Beaujean et al. 1998). In tomato Cry1Ab25 E event the same phenomena seems to be applicable where stable integration accompanied by functional stability of the transgene made the event a successful line.

The commercially released Bt-cotton was developed with full-length $c r y 1 A c$-like gene whose nucleotide alignment study revealed that 'Monsanto 531' cry gene sequence is a hybrid gene where the sequence 1-1398 bp is that of $c r y 1 A b$ gene. We can easily summarize that it was done in order to provide a blend of binding as well as pore formation characteristics in this successful cry gene for raising transgenic cotton and its commercialization. The Bt-cry $1 \mathrm{Ab}$ gene offers higher transformation frequency (24.98 \pm 3.56$)$, optimal expression $(0.02-0.13 \%$ of TSP) and good receptor-binding characteristics and is a promising candidate gene for gene pyramiding strategy to delay insect resistance.

\section{Conclusions}

The Cry1Ac toxin has been reputedly effective against lepidopteron insects, especially $H$. armigera (Mandaokar 
et al. 2000). In the present study, although, the expression of $\operatorname{Tr} c r y 1 A c$ gene was 100 folds higher than the Flcry1Ac gene the latter gave full-protection from $H$. armigera at very low concentration as evident from promising $\mathrm{T}_{0}$ plants (plant ID FlAc7 and FlAc11) and their $\mathrm{T}_{1}$ transgenic population study. The functional role of protoxin segments in Cry-pore forming toxin activity is yet to be studied in detail. The full-length $c r y 1 A c$ gene can be redesigned for higher expression and stability in crop plants and can be pyramided with other cry gene(s) or a hybrid gene can be designed to broaden its toxicity spectrum and efficacy, as a remedy to cope with the problem of insect resistance.

\section{Methods}

Agrobacterium strain and gene constructs

Agrobacterium tumefaciens strain LBA4404 harbouring binary vector pRD400, with modified and truncated 1,845 bp cry1Ac gene having $47.74 \%$ GC content (Sardana et al. 1996; courtesy provided by Prof. I. Altosaar, University of Ottawa, Ottawa, Canada) and pNBRI-1 with modified full-length 3,510 bp cry1Ac gene $47.89 \%$ GC content (Koul 2013) respectively, driven by double enhancer DECaMV35S promoter and neomycin phosphotransferase gene (nptII) for kanamycin resistance in pBIN 20 backbone (Hennegan and Danna 1998) has been used for tomato transformation, as shown in Figure 1A and B. Cultures of A. tumefaciens were grown at $28^{\circ} \mathrm{C}$ in YEB medium containing $20 \mathrm{mg} \mathrm{l}^{-1}$ rifampicin, $50 \mathrm{mg} \mathrm{l}^{-1}$ kanamycin and $50 \mathrm{mg} \mathrm{l}^{-1}$ streptomycin for $24 \mathrm{~h}$ at $200 \mathrm{rpm}$ and utilized for transformation of tomato leaf-discs.

\section{Plant material}

Breeder seeds of Solanum lycopersicum cv. Pusa early dwarf (PED) were obtained from National Seeds Corporation, New Delhi, India and used for Agrobacterium-mediated leaf-disc transformation of tomato.

\section{Tomato transformation and plantlet regeneration}

Tomato seeds were surface sterilized and placed on semi-solid MS medium (Murashige and Skoog 1962), containing B5 vitamins (Gamborg et al. 1968) 3\% (w/v) sucrose (HiMedia Labs, Mumbai, India) and $8 \mathrm{~g} \mathrm{l}^{-1}$ agar (Sigma, USA) followed by incubation at $24 \pm 2^{\circ} \mathrm{C}$ in dark and shifted after three days of 16:8 h light-dark cycle in culture room maintained at $22 \pm 2^{\circ} \mathrm{C}$, illuminated with light intensity of $100 \mu \mathrm{mol} \mathrm{m} \mathrm{m}^{-2} \mathrm{~s}^{-1}$ and $78 \pm 4 \%$ relative humidity. Vegetative leaves from axenic tomato seedlings of 16-18 days, were excised and initially precultured on MS medium supplemented with $2.5 \mathrm{mg} \mathrm{l}^{-1}$ 6-benzyladenine (BAP) $+0.5 \mathrm{mg} \mathrm{l}^{-1}$ indole-3-acetic acid (IAA) for three days prior to Agrobacterium cocultivation (Koul 2013).
Agrobacterium-mediated transformation of tomato was performed by the method described by Koul et al. 2014a, 2014b. Tomato leaf discs were dipped in Agrobacterium suspension $\mathrm{OD}_{600} \approx 0.25-0.3\left(2 \times 10^{9} \mathrm{cfu} \mathrm{ml}^{-1}\right)$, in MS liquid co-cultivation medium supplemented with $100 \mu \mathrm{M}$ acetosyringone (As) for $20 \mathrm{~min}$. The leaf disc explants were dried on sterilized blotting paper and transferred onto semi-solid co-cultivation medium comprising of MS salts $+3 \%(\mathrm{w} / \mathrm{v})$ maltose $+100 \mu \mathrm{M}$ As $+2.5 \mathrm{mg} \mathrm{l}^{-1} \mathrm{BAP}+0.5 \mathrm{mg} \mathrm{l}^{-1}$ IAA and co-cultivated in dark, for two days in the culture room. The explants thereafter were incubated on medium consisting of MS salts $+3 \%(\mathrm{w} / \mathrm{v})$ maltose $+500 \mathrm{mg} \mathrm{l}^{-1}$ cefotaxime $+2.5 \mathrm{mg} \mathrm{l}^{-1} \mathrm{BAP}+0.5 \mathrm{mg} \mathrm{l}^{-1}$ IAA for 5-7 days and transferred to shoot induction medium one (SIM-1) containing MS salts $+3 \%(\mathrm{w} / \mathrm{v})$ maltose $+2.5 \mathrm{mg} \mathrm{l}^{-1} \mathrm{BAP}+$ $0.5 \mathrm{mg} \mathrm{l}^{-1}$ IAA + $250 \mathrm{mg} \mathrm{l}^{-1}$ cefotaxime $+50 \mathrm{mg} \mathrm{l}^{-1}$ kanamycin and incubated for 30 days for the first screening of putative transgenic plants ( $\mathrm{I}^{\text {st }}$ selection). The independent regenerated shoots with a pair of vegetative leaves developed on first cycle of kanamycin screening were identified. These first pair of vegetative leaves were excised and subcultured on the shoot induction medium supplemented with kanamycin (SIM-2) having the same constituents as SIM-1 and incubated for 30 days for subsequent direct second screening and selection. The independent shoots that regenerated after successive $\mathrm{II}^{\text {nd }}$ selection cycles were subcultured on shoot elongation medium (SEM) containing MS medium + $1.0 \mathrm{mg} \mathrm{l}^{-1}$ gibberellic acid $\left(\mathrm{GA}_{3}\right)+3 \%(\mathrm{w} / \mathrm{v})$ sucrose and $50 \mathrm{mg} \mathrm{l}^{-1}$ kanamycin. The transformation frequency percentage for each experiment with respective vector-construct was calculated as total putative transgenic shoots developed after second selection divided by total number of leaf disc explants used, multiplied by 100 . The shoots recovered from SEM medium having 2-3 leaves were transferred to root induction medium (RIM) containing half-strength MS medium $+0.5 \mathrm{mg} \mathrm{l}^{-1}$ indole-3-butyric acid (IBA) $+50 \mathrm{mg} \mathrm{l}^{-1}$ kanamycin $+2 \%$ (w/v) sucrose and $0.8 \%(\mathrm{w} / \mathrm{v})$ agar for 14 days. The rooted plantlets were transferred to plastic pots containing sterilized soilrite (Keltech Energies Ltd. Bengaluru, India) and irrigated with half-strength liquid MS medium devoid of sucrose. The pots were kept in a plant growth chamber (Conviron Adaptis 1000 PG, Canada) set at desired relative humidity starting from 90 to $70 \%$ for 14 days of hardening step and the hardened plantlets were potted in earthen pots filled with soil:sand:farmyard manure (in 3:1:1 ratio) and transferred to glasshouse maintained at $24 \pm 1^{\circ} \mathrm{C}$ under natural light for normal development, flowering and seed setting.

The seeds of promising $\mathrm{T}_{0}$ transgenic plants of tomato were graded on the basis of quantitative Cry1Ac toxin expression, processed, air dried and kept under vacuum at $24 \pm 2^{\circ} \mathrm{C}$. The segregation and selection of promising events in subsequent generations from each transgenic plant were screened on kanamycin-supplemented semi- 
solid medium and Cry1Ac toxin level was estimated by double antibody sandwich enzyme-linked immunosorbent assay (DAS-ELISA). The selected promising transgenic plants showing higher expression of Cry1Ac toxin, normal growth and flowering were analyzed in subsequent generations.

\section{Screening of transgenic plants by PCR}

Genomic DNA from leaves of $\mathrm{T}_{0}$ putative transformed plants as well as control plants was isolated using GenElute plant genomic DNA miniprep kit, according to the manufacturer's instructions (Sigma, USA). PCR amplification of cry $1 A c$ and $n p t I I$ genes from plant genomic DNA (100 ng) was achieved by using set of primers (Additional file 5 : Table S4) designed to amplify 995 bp, 768 bp and 678 bp amplicons of Trcry1Ac and Flcry1Ac and nptII genes respectively, in the GeneAmp ${ }^{\circ}$ PCR system 9700 (PE Biosystems, USA). The $25 \mu \mathrm{l}$ PCR reaction mixture was prepared containing $100 \mathrm{ng}$ plant genomic DNA, $100 \mu \mathrm{M}$ dNTPs mix, $25 \mathrm{ng}$ of each primer, $2 \mathrm{mM} \mathrm{MgSO} 4$ and $1 \mathrm{U}$ Taq DNA polymerase (NEB, USA). Amplification was performed with initial denaturation at $95^{\circ} \mathrm{C}$ for $5 \mathrm{~min}$ followed by 30 cycles, each comprising of denaturation at $94^{\circ} \mathrm{C}$ for $90 \mathrm{sec}$, annealing at $58^{\circ} \mathrm{C}(\operatorname{Trcry} 1 \mathrm{Ac}) / 67^{\circ} \mathrm{C}$ (Flcry $1 A c) / 58^{\circ} \mathrm{C}$ (nptII) for $1 \mathrm{~min}$ and extension at $72^{\circ} \mathrm{C}$ for $3 \mathrm{~min}$ followed by final extension for $5 \mathrm{~min}$ at $72^{\circ} \mathrm{C}$ for 5 min. In all PCR experiments pRD400 plasmid was taken as positive control for $c r y 1 A c$ gene and pNBRI-1 plasmid was taken as positive control for Flcry1Ac gene. Amplified DNA fragments of PCR assays were electrophoresed on $1 \%$ agarose $(\mathrm{w} / \mathrm{v})$ gels, visualized, documented and analyzed on Gel Doc XR (Bio-Rad, USA).

\section{Southern blot hybridization analysis}

Southern blot hybridization analysis was performed to confirm the integration of T-DNA into transformants according to Sambrook and Russell (2001), with few modifications (Koul et al. 2012). Aliquot of $10 \mu \mathrm{g}$ genomic DNA purified from untransformed and transgenic plants was digested overnight with EcoRI (pRD400 transformants) and SalI (pNBRI-1 transformants) cutting at single site within the T-DNA. The digested genomic DNA was separated by gel electrophoresis and transferred onto Bio Bond Plus nylon membrane (Sigma, USA). The blots were hybridized at $58^{\circ} \mathrm{C}$ for $24 \mathrm{~h}$ with $1,845 \mathrm{bp}$ and 3,510 bp fragment of cry1Ac and FlCry1Ac genes respectively, radio labeled with $\alpha \mathrm{P}^{32} \mathrm{dCTP}$ (BRIT, Mumbai India), washed under stringent conditions, exposed to Fuji screen for $48 \mathrm{~h}$ followed by scanning and documentation on Typhoon Trio Plus phosphoimager (GE Healthcare Life Sciences AB, Sweden).

\section{RT-PCR and quantitative real-time PCR}

RT-PCR analysis of $\mathrm{T}_{0}$ and $\mathrm{T}_{1}$ transgenic plants was done by synthesis of first-strand of cDNA with enhanced Avian RT-PCR kit using $5 \mu \mathrm{g}$ of total RNA purified from the transgenic plant according to manufacturer's instructions (Sigma, USA). The relative quantity of cry1Ac transcripts in transgenic tomato plants was analyzed by quantitative PCR performed in StepOne real-time PCR system (Applied Biosystems, USA) using Quantifast SYBR green PCR kit (Qiagen, Germany). Tomato $\beta$-actin gene (GenBank accession no. U60482) was used as endogenous control in all real-time PCR assays. The nucleotide sequences of the set of primers for TrcrylAc gene were, forward; 5'-ACACAGTTTCTGCTCAGCGA GTT-3' and reverse; 5' - ACCAAAGATACCCCAGATGA TGTC-3', primers for Flcry1Ac gene were, forward; $5^{\prime}-\mathrm{CT}$ TCTCTGGAACTGCTGGTGTGA-3' and reverse; $5^{\prime}$-CA GCCTTTTGGGCTCTTTCA-3', while for $\beta$-actin gene forward; 5'-GCTGGATTTGCTGGAGATGATGA-3' and reverse; 5'-TCCATGTCATCCCAATTGCTAAC-3' giving an amplicon of 99, 101 and 194 bp respectively.

Total RNA extracted from $100 \mathrm{mg}$ of leaf tissues was reverse transcribed into cDNA and used as template in real-time PCR assays with $c r y 1 A b$ and $\beta$-actin genespecific primers. Reverse transcription reaction was performed at $50^{\circ} \mathrm{C}$ for $10 \mathrm{~min}$ with initial denaturation at $95^{\circ} \mathrm{C}$ for $5 \mathrm{~min}$ (for activation of Hot-start Taq polymerase) followed by 40 amplification-cycles comprising of $10 \mathrm{~s}$ denaturation at $95^{\circ} \mathrm{C}$ and combined annealing and extension for $30 \mathrm{~s}$ at $60^{\circ} \mathrm{C}$ in $25 \mu \mathrm{l}$ reaction mixture, according to manufacturer's instructions (Qiagen, Germany). The relative values obtained from the quantitation of mRNA were expressed as $2^{-\Delta \Delta \mathrm{Ct}}$ where $\Delta \mathrm{Ct}$ represents the difference between $\mathrm{Ct}$ (cycle threshold) values of a target and the endogenous control ( $\beta$-actin) in the same sample and $\Delta \Delta \mathrm{Ct}$ is the difference between the $\Delta \mathrm{Ct}$ value of a particular sample and that of the reference sample. The quantitative data of real-time PCR represent mean values with standard error of three independent experiments with three replicates of the transgenic plant samples.

\section{Western immunoassay}

Western immunoblotting of the transgenic plants expressing Cry1Ac toxin was performed using the cell-free extract of leaf tissues. Aliquots of the cell-free extracts were boiled for $10 \mathrm{~min}$ with $2 \times$ sample loading dye (50 mM Tris- $\mathrm{HCl}$ pH 6.8, 100 mM DTT, 2\% SDS, 0.1\% bromophenol blue, 10\% glycerol) and electrophoresed on 10\% denaturing SDS-PAGE (Laemmli 1970). Protein bands were visualized following Coomassie blue staining and the other set of SDS-PAGE was transferred onto immunoblot $^{\text {Tix }}$ PVDF membrane (Bio-Rad, USA) using trans-blot SD semi-dry transfer cell (Bio-Rad, USA) in transfer buffer (25 mM Tris base, $192 \mathrm{mM}$ glycine, 
pH 8.3 and $0.1 \%$ SDS). The membrane was blocked for 2 $\mathrm{h}$ at $25^{\circ} \mathrm{C}$ in blocking buffer and incubated with primary antibody (rabbit polyclonal to Bt-Cry1Ac toxin, Amar Diagnostics, India) diluted to 1:1000 ratio in blocking buffer, for $2 \mathrm{~h}$ at $25^{\circ} \mathrm{C}$. The membranes were washed four times with PBST, incubated in blocking buffer for 1 $\mathrm{h}$ followed by incubation with secondary antibody (goat polyclonal to rabbit IgG alkaline phosphatase conjugated antibody) at 1:5000 dilutions for $2 \mathrm{~h}$ at $25^{\circ} \mathrm{C}$ and developed with BCIP-NBT substrate solution (Sigma, USA).

\section{Quantitative estimation of Bt-toxin}

Vegetative leaves from 12 weeks old transgenic tomato plants of $T_{0}$ and $T_{1}$ generations were used for protein extraction by grinding in 1:10 (w/v) ratio of plant tissue to PBST buffer ( $\mathrm{pH} 7.4$ ), in liquid nitrogen. The total soluble protein (TSP) concentration in cell-free extracts was determined by Bradford dye-binding procedure with bovine serum albumin (BSA) as standard protein (Bradford 1976). The quantitative estimation of expressed recombinant Cry1Ac (toxin) in cell-free extracts of transgenic plants was determined by double antibody sandwich enzyme-linked immunosorbent assay (DAS-ELISA), using peroxidase labeled PathoScreen kit for Bt-Cry1Ab/1Ac protein (Agdia, USA). Cell-free extracts (100 ng TSP) from leaves of transgenic plants were dispensed into wells of ELISA plate, pre-coated with primary antibody followed by reaction with secondary antibody conjugated with alkaline phosphatase to develop colour and detection of Cry1Ac toxin was monitored at $650 \mathrm{~nm}$ using SpectraMax 340PC spectrophotometer (Molecular Devices, USA).

\section{Insect bioassay}

The larval populations of $H$. armigera were reared in the insectary on an artificial diet (Gupta et al. 2004) at $26 \pm$ $2^{\circ} \mathrm{C}, 70 \%$ relative humidity on $14 \mathrm{~h}$ light and $10 \mathrm{~h}$ dark regime. The detached leaves from fourth to sixth nodes of untransformed control, $\mathrm{T}_{0}$ and $\mathrm{T}_{1}$ transgenic plants were washed thoroughly with distilled water, blotted dry and placed in a plastic container with 10 second instar larvae of $H$. armigera per leaf, in three replicates. Feeding was allowed for 48-96 $\mathrm{h}$ and the data on larval weight and percent mortality were analyzed statistically (SPSS Inc., USA). Each experiment was repeated thrice with three replicates and results were co-related to the quantitative expression of Cry1Ac toxin.

\section{Statistical analysis}

Each experiment was performed with three replicates, unless otherwise mentioned and repeated at least three times. $T_{1}$ seeds were germinated on MS basal medium supplemented with $50 \mathrm{mg} \mathrm{l}^{-1}$ kanamycin and subjected to $\chi^{2}$ fitness test for progeny segregation to compare the expected and observed data. All graphs were prepared using Sigma Plot software (Sigma Plot, USA).

\section{Additional files}

\begin{abstract}
Additional file 1: Table S1. Tomato transformation using pRD400 and pNBRI-1 for regeneration of transgenic plants.

Additional file 2: Table S2. Insect mortality data of $T_{0}$ transgenic plants.

Additional file 3: Table S3. Segregation analysis of nptll gene in $T_{1}$ seeds developed with vector pRD400 and pNBRI-1.

Additional file 4: Figure S1. Quantitative assessment of Bt-Cry1Ab protein in different $T_{0}$ plants and selected $T_{1}$ population by A \& B Double antibody sandwich enzyme-linked immunosorbent assay (DAS-ELISA) as percentage of total soluble protein (TSP) (striped bar) and corresponding insect mortality of Helicoverpa armigera (open square) and Spodoptera litura (open circle). Average quantity of Bt-Cry1 Ab protein in transgenic plants is shown as \% TSP \pm standard deviation on the top of histogram bars and also indicated by horizontal mark for individual transgenic plant. ' $n$ ' is the number of $T_{1}$ transgenic population from each parent.
\end{abstract}

Additional file 5: Table S4. Sets of forward and reverse primers used in the experiments.

\section{Abbreviations}

As: Acetosyringone; BAP: 6-Benzyladenine; BBMV: Brush bordered membrane vesicle; bp: Base pairs; cfu: Colony forming units; Cry: Crystal protein; DAS-ELISA: Double antibody sandwich enzyme-linked immunosorbent assay; DECaMV35S: CaMV35S promoter with duplicated enhancer;

$G_{3}$ : Gibberellic acid IAA: Indole-3-acetic acid; IBA: Indole-3-butyric acid; MS: Murashige and Skoog's medium; nptll: Neomycin phosphotransferase; PBST: Phosphate buffered saline with Tween-20; PCR: Polymerase chain reaction; RIM: Root induction medium; SIM: Shoot induction medium; SEM: Shoot elongation medium; TSP: Total soluble protein.

\section{Competing interests}

The authors declare that they have no competing interests.

\section{Authors' contributions}

DVA and IS conceived the project. BK performed tomato transformation, raised the transgenic plants, carried out molecular analysis, insect bioassays of the transgenic tomato plants and analysis of the results. RY performed quantitative estimation of BT-content in transgenic lines. BK wrote the manuscript. All the authors have read and approved the manuscript.

\section{Acknowledgements}

We thank to Dr. C. S. Nautiyal, Director, Council for Scientific and Industrial Research-National Botanical Research Institute, Lucknow, India for valuable suggestions, infrastructural support and CSIR, New Delhi, for providing financial grants for research work under the network project, NWP-03. Thanks are due to Prof. I. Altosaar, Department of Biochemistry, University of Ottawa, Canada for providing modified synthetic truncated Bt-cry 1 Ac gene and Dr. P. K. Singh, Plant Molecular Biology Lab, CSIR-NBRI, Lucknow, India for Bt-FIcrylAc gene construct. We also thank Dr. S. Chandrasekhar for valuable support; Mr. S.M.H. Abidi for conducting insect mortality bioassays with transgenic tomato plants.

\section{Author details}

${ }^{1}$ Department of Biotechnology and Biosciences, Lovely Professional University (LPU), Jalandhar-Delhi G.T. Road (NH-1), Phagwara 144411, Punjab, India. ${ }^{2}$ Plant Transgenic Lab, CSIR-National Botanical Research Institute, Rana Pratap Marg, P.O. Box 436, Lucknow 226001 , UP, India.

Received: 17 September 2014 Accepted: 20 April 2015

Published online: 30 April 2015

\section{References}

Barton KA, Whiteley HR, Yang NS (1987) Bacillus thuringiensis $\delta$-endotoxin expressed in transgenic Nicotiana tabaccum provides resistance to lepidopteran insects. Plant Physiol 85:1103-1109 
Beaujean A, Sangwan RS, Hodges M, Sangwan-Norreel BS (1998) Effect of ploidy and homozygosity on transgene expression in primary tobacco transformants and their androgenetic progenies. Mol Gen Genet 260:362-371

Bradford MM (1976) A rapid and sensitive method for the quantitation of microgram quantities of protein utilizing the principle of protein-dye binding. Anal Biochem 72:248-254

Chrispeels MJ, Sadava DE (1994) Plants, genes and agriculture, 1st edn. Jones and Bartlett Publishers, Boston, MA

De Rocher EJ, Vargo-Gogola TC, Diehn SH, Green PJ (1998) Direct evidence for rapid degradation of Bacillus thuringiensis toxin mRNA as a cause of poor expression in plants. Plant Physiol 117:1445-1461

Gamborg OL, Miller RA, Ojima K (1968) Nutrient requirements of suspension culture of soybean root cells. Exp Cell Res 50:151-158

Gatehouse JA (2008) Biotechnological prospects for engineering insect-resistant plant. Plant Physiol 146:881-887

Gomez I, Sanchez J, Munoz-garay C, Matus V, GILL SS, Soberon M, Bravo A (2014) Bacillus thuringiensis Cry1A toxins are versatile proteins with multiple modes of action: two distinct pre-pores are involved in toxicity. Biochem J 459:383-396

Gupta GP, Birah A, Ravi S (2004) Development of artificial diet for mass rearing of American bollworm (Helicoverpa armigera). Ind J Agri Sci 74:548-557

Heinrichs A (2008) Small RNAs: united in silence. Nat Rev Mol Cell Biol 9:496

Hennegan KP, Danna KJ (1998) pBIN20: An improved binary vector for Agrobacterium-mediated transformation. Plant Mol Biol Rep 16(2):129-131

Hobbs SLA, Warkentin TD, DeLong CMO (1993) Transgene copy number can be positively or negatively associated with transgene expression. Plant Mol Biol 21:17-26

James C (2012) Global status of commercialized Biotech/GM Crops: 2012 (ISAAA Brief No. 44). ISAAA, Ithaca, NY

Jurat-Fuentes $\mathrm{J}$, Adang MJ (2006) Cry toxin mode of action in susceptible and resistant Heliothis virescens larvae. J Invertebrate Pathol 92:166-171

Koul B (2013) Expression of insecticidal toxin coded by modified full-length and truncated Bt-crylAc genes in transgenic tomato for assessment of their stability and efficacy against target insects, PhD thesis. Banasthali Vidyapith, Rajasthan, India

Koul B, Yadav R, Sanyal I, Sawant S, Sharma V, Amla DV (2012) Cis-acting motifs in artificially synthesized expression cassette leads to enhanced transgene expression in tomato (Solanum lycopersicum L.). Plant Physiol Biochem 61:131-141

Koul B, Srivastava S, Amla DV, Sanyal I (2014a) Establishment and optimization of Agrobacterium-mediated transformation and regeneration of tomato (Solanum lycopersicum L.). Int J Biosci 4:51-69

Koul B, Srivastava S, Sanyal I, Tripathi BN, Sharma V, Amla DV (2014b) Transgenic tomato line expressing modified Bacillus thuringiensis cry 1 Ab gene showing complete resistance to two lepidopteran pests. Springer Plus 3:84-96

Koziel MG, Beland GL, Bowman C, Carozzi NB, Crenshaw R, Crossland L, Dawson J, Desai N, Hill M, Kadwell S, Launis K, Lewis K, Maddox D, McPherson K, Meghji MR, Merlin E, Rhodes R, Warren GW, Wright M, Evola SV (1993) Field performance of elite transgenic maize plants expressing an insecticidal protein derived from Bacillus thuringiensis. Bio/Tech 11:194-200

Kranthi KR, Naidu S, Dhawad CS, Tatwawadi A, Mate K, Patil E, Bharose AA, Behere GT, Wadaskar RM, Kranthi S (2005) Temporal and intra-plant variability of Cry1Ac expression in Bt-cotton and its influence on the survival of the cotton bollworm, Helicoverpa armigera (Hübner) (Noctuidae: Lepidoptera). Curr Sci 89:291-298

Laemmli UK (1970) Cleavage of structural proteins during the assembly of the head of bacteriophage T4. Nature 227:680-685

Mandaokar AD, Goyal RK, Shukla A, Bisaria S, Bhalla R, Reddy VS, Chaurasia A, Sharma RP, Altosaar I, Ananda Kumar P (2000) Transgenic tomato plants resistant to fruit borer (Helicoverpa armigera Hübner). Crop Prot 19:307-312

Murashige T, Skoog F (1962) A revised medium for rapid growth and bioassays with tobacco tissue cultures. Physiol Plant 15:473-497

Murray EE, Lotzer J, Eberle M (1989) Codon usage plant genes. Nucl Acids Res 17:477-498

Pardo Lopez L, Soberon M, Bravo A (2013) Bacillus thuringiensis insecticidal three-domain Cry toxins: mode of action, insect resistance and consequences for crop protection. FEMS Microb Rev 37:3-22

Peferoen M (1997) Progress and prospects for field use of Bt genes in crops. Trends Biotechnol 15:173-177

Perlak FJ, Deaton RW, Armstrong TA, Fuchs RL, Sims SR, Greenplate JT, Fischhoff DA (1990) Insect-resistant cotton plants. Bio/Tech 8:939-943
Perlak FJ, Fuchs RL, Dean DA, McPherson SL, Fischhoff DA (1991) Modification of the coding sequences enhances plant expression of insect control protein genes. Proc Natl Acad Sci U S A 88:3324-3328

Perlak FJ, Oppenhuizen M, Gustafson K, Voth R, Sivasupramaniam S, Herring D, Carey B, Ihring RA, Roberts JK (2001) Development and commercial use of Bollgard $^{\oplus}$ cotton in the USA-early promises versus today's reality. Plant J 27:489-501

Purcell JP, Oppenhuizen M, Wofford T, Reed AJ, Perlak FJ (2004) The story of Bollgard cotton. In: Christou P, Klee H (eds) Handbook of plant biotechnology, John Wiley \& Sons., pp 1147-1163

Rawat P, Singh AK, Ray K, Chaudhary B, Kumar S, Gautam T, Kanoria S, Kaur G, Kumar P, Pental D, Burma PK (2011) Detrimental effect of expression of Bt endotoxin Cry1Ac on in vitro regeneration, in vivo growth and development of tobacco and cotton transgenics. J Biosci 36:363-376

Sachs ES, Benedict JH, Stelly DM, Tayor JF, Altman DW, Berberich SA, Davis SK (1998) Expression and segregation of genes encoding Cry1A insecticidal proteins in cotton. Crop Sci 38:1-11

Sambrook J, Russell DW (2001) Molecular cloning: a laboratory manual. (Third Edition), Vol. I, II and III. Cold Spring Harbor Laboratory Press, Cold Spring Harbor, New York

Sanahuja G, Banakar R, Twyman RM, Capell T, Christou P (2011) Bacillus thuringiensis: a century of research, development and commercial applications. Plant Biotechnol J 9:283-300

Sardana R, Dukiandjiev S, Giband M, Cheng X, Cowan K, Sauder C, Altosaar I (1996) Construction and rapid testing of synthetic and modified toxin gene sequences $c r y 1 \mathrm{~A}(b \& c)$ by expression in maize endosperm culture. Plant Cell Rep 15:677-681

Schnepf E, Crickmore N, Van Rie J, Lereclus D, Baum J, Feitelson J, Zeigler DR, Dean DH (1998) Bacillus thuringiensis and its pesticidal crystal proteins. Microbiol Mol Biol Rev 62:775-806

Sharma S (2010) Insect resistance: current perspectives in research. Biotech Articles. http://www.biotecharticles.com/Biotech-Research-Article/Insect-Resistance-Current Perspectives-in-Research-481.html

Shrivastava D (2012) Gene targeting based genetic transformation in brinjal (Solanum melongena L.), Ph.D. Thesis. Guru Gobind Singh Indraprastha University, Delhi, India

Vaeck M, Reynaerts A, Hofte H, Jansens S, De Beuckeleer M, Dean C, Zabeau M, Van Montagu M, Leemans J (1987) Transgenic plants protected from insect attack. Nature 328:33-37

Wilson C, Bellen HJ, Gehring WJ (1990) Position effects on eukaryotic gene expression. Ann Rev Cell Biol 6:679-714

\section{Submit your manuscript to a SpringerOpen ${ }^{\mathcal{D}}$ journal and benefit from:}

- Convenient online submission

$\checkmark$ Rigorous peer review

- Immediate publication on acceptance

- Open access: articles freely available online

- High visibility within the field

- Retaining the copyright to your article

Submit your next manuscript at $>$ springeropen.com 